\title{
Resolving the differences between system development and system operation using STAMP: A road safety case study in a low-income setting
}

Omar Faruqe Hamim ${ }^{\mathrm{a}}$, Mithun Debnath ${ }^{\mathrm{b}}$, Shahnewaz Hasanat-E-Rabbi ${ }^{\mathrm{c}}$, Md. Shamsul Hoque $^{\mathrm{d}}$, Rich C. McIlroy ${ }^{\mathrm{e}}$, Katherine L. Plant ${ }^{\mathrm{e}}, \&$ Neville A. Stanton $^{\mathrm{e}}$

$\mathrm{a}^{*}$ Corresponding author. Department of Civil Engineering, Bangladesh University of Engineering and Technology, Dhaka-1000, Bangladesh. Email: hamim1204007@ gmail.com

${ }^{\mathrm{b}}$ Department of Civil Engineering, Ahsanullah University of Science \& Technology, 141 \& 142, Love Road, Dhaka-1208, Bangladesh

c Accident Research Institute, Bangladesh University of Engineering and Technology, Dhaka-1000, Bangladesh

${ }^{\mathrm{d}}$ Department of Civil Engineering, Bangladesh University of Engineering and Technology, Dhaka-1000, Bangladesh

${ }^{\mathrm{e}}$ Human Factors Engineering, Transportation Research Group, University of Southampton, Southampton, UK

\begin{abstract}
Road safety strategies adopted worldwide have made significant progress in reducing road trauma, but have stagnated more recently. The situation in low- and middleincome countries is even worse with no significant decrease in fatality rates. Safety researchers have argued that adopting sociotechnical systems approaches is necessary to make significant advancements and improvements. The aim of this study was to develop a control structure model of the Bangladesh road safety system by identifying the actors and organizations involved across the system. Expert stakeholders were identified and interviewed, and relevant information was gathered in order to generate the Systems Theoretic Accident Model and Process (STAMP) control structure model. Throughout the analysis of this model, differences in the control and feedback mechanisms of the system were identified, and road safety intervention recommendations were made. Future research should also predict potential risks within the system and propose proactive and preventative countermeasures.
\end{abstract}

Keywords: STAMP, sociotechnical system, road safety, control structure, systems thinking.

\section{Practitioner Summary}

In this paper, a STAMP control structure model of the Bangladesh road safety system is developed, and the involved actors are identified. Based on interviews and workshops with expert stakeholders, differences in the controls and feedback mechanisms in the system were identified, and road safety intervention recommendations were made. 


\section{Introduction}

Worldwide, road safety has become a serious concern for global leaders as 1.35 million people are killed each year from road collisions (WHO, 2018). Road traffic injury has become the $8^{\text {th }}$ leading cause of death for people of all ages, accounting for $2.5 \%$ of all deaths around the world; it is the only non-disease related issue among the top ten causes of death (Salmon and Lenné, 2015; WHO, 2018). Road safety practitioners have adopted several strategies to reduce worldwide road trauma, but the progress is far from uniform across countries. In most highly motorized countries, significant reductions in fatalities and injuries from road crashes have been made over the last four decades (Elvik, 2010), but according to WHO (2018), three times higher death rates are observed in low-income countries than in high-income countries, despite the fact that only $1 \%$ of world's motor vehicles ply the roads of low-income countries.

Intervention strategies based on contemporary approaches (e.g., Vision Zero) have contributed to significant reductions in road crashes in the past, but these may have become exhausted within the dynamic road transport system because they do not fully account for the inherent complexity of transportation systems, which involve a wide range of actors contributing at different levels of the system (Cornelissen et al., 2015; Larsson et al., 2010; McClure et al., 2015; Salmon et al., 2012a; Salmon and Lenné, 2015). In response to this global crisis, road safety researchers and practitioners have argued for the adoption of new systems-thinking approaches (Larsson et al., 2010; Read et al., 2013; Salmon and Lenné, 2015; Stanton et al, 2019a). Successful applications of systems thinking methodologies in various safety-critical domains (e.g. Salmon et al. 2013; Carayon et al., 2015; Parand et al., 2018; Thatcher et al., 2020) suggest that such approaches may aid road trauma reductions as well (Larsson et al., 2010; Salmon et al., 2012a; Read et al., 2013). 
Salmon et al. (2016) argues that considering the road transport system as a whole and emphasizing not only the behavior of road users, but also focusing on the higher system factors that influence road user behavior and trauma (e.g. rules and regulations, road safety policies and strategies, design standards and guidelines), will help when developing appropriate countermeasures. Evidence of successful applications of systems thinking in road transport systems can be found in the works of Cornelissen et al. (2013), Newnam and Goode (2015), Salmon et al. (2012a, 2016), and Salmon and Read (2019). It has also been shown that modeling road systems incorporating systemic influences on road user behavior and road trauma is possible (Goh and Love, 2012; McClure et al., 2015); this helps to identify contributory factors beyond the road users and their immediate surrounding (Salmon and Lenné, 2015; Stanton et al, 2019a), as collisions emerge from complex sociotechnical systems in which factors across the whole system contribute (Dekker, 2011; Leveson, 2004; Rasmussen, 1997). It has been revealed that road transport is indeed a complex sociotechnical system consisting of many inter-related components (Larsson et al., 2010; Salmon et al., 2012a), yet still there is a bias towards road users and physical environments in road trauma reporting. Given the existence of complex interactions in a dynamic road transport system, Holman et al. (2020) and Davis et al. (2020) argue that ergonomics methodologies should evolve as the problems at systems level are increasing in scale, ambition, and complexity.

Coping with the complexity of road transport, sociotechnical approaches are gaining popularity, and have been used to support the analyses of road traffic collision related behaviors and the development of relevant interventions (Salmon and Lenné, 2015; Larsson et al. 2010; Salmon et al. 2012a). Similarly, McIlroy et al. (2019) and Hamim et al. $(2019,2020 a, 2020 b)$ focused on the fact that systems-based research could bring a paradigm shift in road safety in low and middle-income countries. This area is, however, 
still in its infancy, with the large majority of related work being conducted in high-income settings; however, the need has been recognized by prominent researchers in the field. For example, Salmon et al. (2016) developed a control structure model of the road transport system in Queensland, Australia and pointed out that the structures of the road transport systems of highly motorized, high-income nations are likely to be similar, but that the scenario is likely to be different in low- and middle-income settings.

The aim of this paper is to apply Systems Theoretic Accident Model and Process (STAMP; Leveson, 2004) to develop a control structure model of the Bangladesh road safety system, from both system development and system operation perspectives, in order to identify the controls enacted and feedback acquired by those actors. Further, the differences in controls and feedback mechanisms between the development and operation phase of the road system which hinder road safety interventions in Bangladesh are examined, with a view to generalize (tentatively) to other low-income countries.

\section{Methodology}

\subsection{STAMP methodology}

STAMP (Leveson, 2004) is a technique capable of recognizing incidents as emergent phenomenon that arise from inadequately controlled, complex, nonlinear interactions (Kazaras et al., 2014). It is based on Rasmussen's (1997) Risk Management Framework, a hierarchical description of a system, with those at higher levels of the hierarchy exerting control over, and receiving feedback from those at lower levels (Lintern and Kugler, 2017) It is a systematic, top-down approach to risk assessment, where emphasis is put on behavioral safety constraints that are enforced on a systemic level rather than emphasizing the 'root-cause', which has a limiting, blame orientation (Jamot and Park, 2019). A generic control structure model is presented in Figure 1 (Leveson, 2004), where system 
development is shown on the left-hand side, and system operation on the right. It has been argued by Leveson (2012) that during the development phase of a system, safety must be included in the design; during the operation phase, safety partly depends on the design of the system as well as on its effective operation.

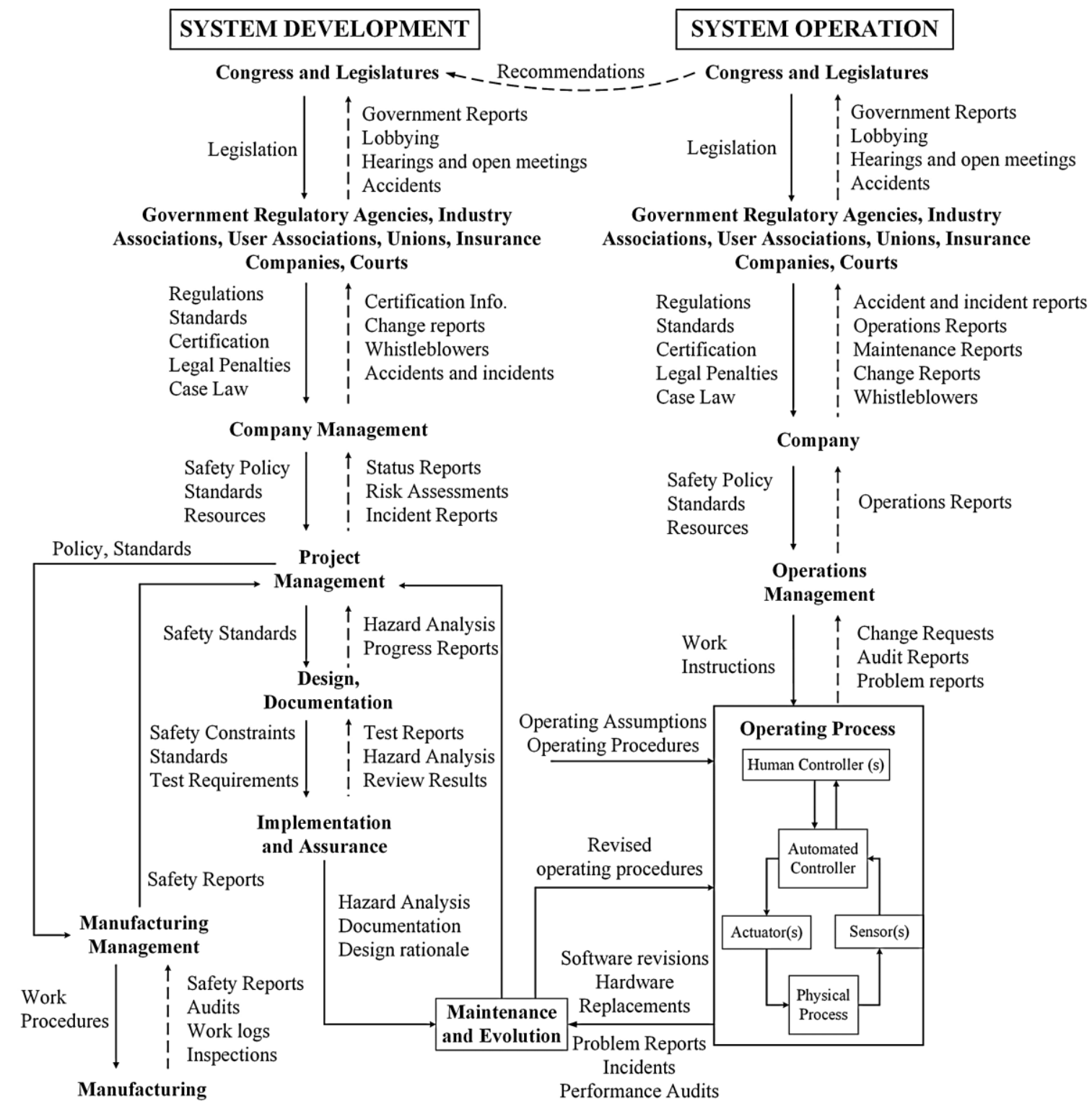

Figure 1: STAMP generic control structure involving development and operation phase (Adapted from Leveson, 2004) 
The first step of developing the STAMP control structure model of the Bangladesh road safety system was to incorporate into the diagram structure those actors identified by McIlroy et al. (2019) in their development of an Actor Map of road transport in Bangladesh. Where it was considered appropriate, and following discussion among the current authors, a number of actors additional to those identified by McIlroy et al. (2019) were also included. Initially, a draft control structure model was prepared by the lead author and was reviewed by the other authors. Feedback was incorporated, and the initial model refined. All analysists met in a round-table discussion and proposed modifications until consensus was reached regarding the structural components (and their inter-relationships) depicted in the model. Following Salmon et al. (2016), actors and organizations were also considered in terms of their formal decision-making authority, i.e., whether each actor present does or does not have such authority. Decisions in this regard were again made initially by the current first author and discussed during initial model refinement with the other authors. The purpose of classifying the actors in this way was to explicitly represent those actors having greater responsibility for overall the system functioning. Development of the control structure model was initially based on information derived from a variety of publicly available sources, including road safety system documentation (e.g., road rules and regulations, road safety strategies, policy documents), stakeholder websites (e.g. the Ministry of Road, Transport and Bridges website), and the academic literature (e.g. ScottParker et al., 2015; Newnam and Goode, 2015; Salmon et al., 2016). Following initial model development, one stakeholder workshop along with a number of stakeholder interviews were conducted. These served to supplement, refine, and finally validate the model.

\subsubsection{Participants}


In order to ensure a comprehensive refinement and validation exercise, workshop and interview participants were sought from different levels of the system, from both the development and operation aspects of the Bangladesh road safety system. Each of the participants had at least 10 years of experience in their field of expertise. A brief overview regarding the role, field of expertise, and experience level of the interview participants is provided in Table 1. The 16 interviewees had an average age of 51.4 years $(\mathrm{SD}=6.8)$ and had, on average, 20.8 years' experience in their field $(\mathrm{SD}=5.7)$. In addition to the interviews, 18 participants all currently working as Additional Superintendents of Police (in the Bangladesh Police force) participated in a workshop. The workshop's 18 participants had an average age of 37 years $(S D=1.2)$, and average experience of 10.4 years $(S D=0.8)$. As ethical approval procedures are not well established in Bangladesh, ethical approval for the study was granted by the University of Southampton's ethics board (a partner in the wider project of which this research forms a part; ethics ID 54491).

At least one person from all system levels was interviewed where possible; however, there were no representatives from either system operation or development for the topmost and bottom-most levels, namely International Context and Level 5 ('Operating Processes and Environment' in system operation, and 'Design and Assurance Processes' in system development). Stakeholder interviews from Level 1 ('Parliament and Legislatures'), official websites and academic literature helped identifying the control and feedback mechanisms present between 'International Organizations' and other levels. Level 5 in both system development and system operation concerns the processes involved in project implementation and operation rather than the impact of any certain organization, so the analysis was based on the academic literature, and on the experience and knowledge of the authors. Some of the actors represented dual roles, for example 'Assistant Professor, ARI' represents 'Road Safety Researchers' at Level 4, as well as the 'Accident Research 
Institute' at Level 3. Also, 'Project Leader' corresponds to Level 4 ('Project Management')

in system development as well as 'Engineering Consultant' and 'Highway Designers' at

Level 4 of system operation.

Table 1. Interview participant details

\begin{tabular}{|c|c|c|c|c|c|}
\hline System Level & $\begin{array}{c}\text { Operations, } \\
\text { Development, or Both }\end{array}$ & $\begin{array}{l}\text { Organization } \\
\text { Represented }\end{array}$ & Participant Role & Expertise & $\begin{array}{l}\text { Experience } \\
\text { Level }\end{array}$ \\
\hline \multirow[t]{4}{*}{$\begin{array}{l}\text { Level 1: Parliament \& } \\
\text { Legislatures }\end{array}$} & Both & $\begin{array}{c}\text { National Road Safety } \\
\text { Council }\end{array}$ & Member & $\begin{array}{c}\text { Road Safety Planning } \\
\text { and Policy Development }\end{array}$ & 20 years \\
\hline & Both & $\begin{array}{l}\text { Bangladesh Planning } \\
\text { Commission }\end{array}$ & Division Chief & National Level Planning & 25 years \\
\hline & Both & $\begin{array}{c}\text { Ministry of Road, } \\
\text { Transport and Bridges }\end{array}$ & Joint Chief & $\begin{array}{l}\text { Road Infrastructures } \\
\text { Planning and } \\
\text { Development }\end{array}$ & 20 years \\
\hline & Both & $\begin{array}{l}\text { Bangladesh Parliament, } \\
\text { and Parliamentary } \\
\text { Standing Committee }\end{array}$ & Member & Legislation & 30 years \\
\hline \multirow{4}{*}{$\begin{array}{c}\text { Level 2: Government } \\
\text { Agencies, Industry } \\
\text { Associations, User } \\
\text { Groups, Insurance } \\
\text { Companies, Courts, } \\
\text { Universities }\end{array}$} & Both & $\begin{array}{l}\text { Roads and Highways } \\
\text { Department }\end{array}$ & $\begin{array}{l}\text { Additional Chief } \\
\text { Engineer }\end{array}$ & $\begin{array}{l}\text { Road Safety and } \\
\text { Infrastructure } \\
\text { Development } \\
\end{array}$ & 25 years \\
\hline & Both & $\begin{array}{l}\text { Roads and Highways } \\
\text { Department }\end{array}$ & $\begin{array}{l}\text { Superintending } \\
\text { Engineer }\end{array}$ & $\begin{array}{l}\text { Road Safety and } \\
\text { Infrastructure } \\
\text { Development }\end{array}$ & 18 years \\
\hline & Both & $\begin{array}{l}\text { Roads and Highways } \\
\text { Department }\end{array}$ & $\begin{array}{l}\text { Superintending } \\
\text { Engineer }\end{array}$ & $\begin{array}{l}\text { Road Safety and } \\
\text { Infrastructure } \\
\text { Development } \\
\end{array}$ & 18 years \\
\hline & Both & $\begin{array}{l}\text { Bangladesh Road } \\
\text { Transport Authority }\end{array}$ & Director & $\begin{array}{c}\text { Road Transport } \\
\text { Regulation }\end{array}$ & 20 years \\
\hline \multirow[t]{6}{*}{$\begin{array}{c}\text { Level 3: Operational } \\
\text { Delivery \& } \\
\text { Management }\end{array}$} & Both & $\begin{array}{l}\text { Local Government } \\
\text { Engineering } \\
\text { Department } \\
\end{array}$ & Project Director & $\begin{array}{l}\text { Road Safety and } \\
\text { Infrastructure } \\
\text { Development } \\
\end{array}$ & 22 years \\
\hline & Both & $\begin{array}{l}\text { Local Government } \\
\text { Engineering } \\
\text { Department } \\
\end{array}$ & Project Director & $\begin{array}{l}\text { Road Safety and } \\
\text { Infrastructure } \\
\text { Development }\end{array}$ & 22 years \\
\hline & Both & $\begin{array}{l}\text { Dhaka Transport Co- } \\
\text { ordination Authority }\end{array}$ & Traffic Engineer & $\begin{array}{l}\text { Urban Road Planning } \\
\text { and Coordination }\end{array}$ & 18 years \\
\hline & Both & $\begin{array}{c}\text { Rajdhani Unnayan } \\
\text { Kartipakkha (RAJUK) }\end{array}$ & Project Director & $\begin{array}{c}\text { Urban Infrastructures } \\
\text { Planning }\end{array}$ & 20 years \\
\hline & Both & $\begin{array}{c}\text { Fire Service and Civil } \\
\text { Defence }\end{array}$ & Director & $\begin{array}{l}\text { Emergency Response } \\
\text { Service }\end{array}$ & 25 years \\
\hline & Both & $\begin{array}{l}\text { Accident Research } \\
\text { Institute, BUET }\end{array}$ & \multirow{2}{*}{$\begin{array}{l}\text { Assistant Professor and } \\
\text { member of Accident } \\
\text { Research Institute (dual } \\
\text { role) }\end{array}$} & \multirow[t]{2}{*}{ Road Safety Research } & \multirow[t]{2}{*}{10 years } \\
\hline \multirow{4}{*}{$\begin{array}{c}\text { Level 4: Project } \\
\text { Management Team } \\
\text { (System Development)/ } \\
\text { Local Management and } \\
\text { Supervision (System } \\
\text { Operation) }\end{array}$} & Operations & $\begin{array}{l}\text { Road Safety } \\
\text { Researchers }\end{array}$ & & & \\
\hline & Operations & $\begin{array}{l}\text { Road Safety } \\
\text { Researchers }\end{array}$ & $\begin{array}{l}\text { Assistant Professor, } \\
\text { Accident Research } \\
\text { Institute, BUET } \\
\end{array}$ & Road Safety Research & 10 years \\
\hline & Development & Project Manager & \multirow{2}{*}{$\begin{array}{l}\text { Project leader and } \\
\text { Engineering and } \\
\text { highway design } \\
\text { consultant (dual role) }\end{array}$} & \multirow[t]{2}{*}{$\begin{array}{c}\text { Project Management, } \\
\text { Engineering Consultancy }\end{array}$} & \multirow[t]{2}{*}{30 years } \\
\hline & Operations & $\begin{array}{l}\text { Engineering and } \\
\text { Highway Design }\end{array}$ & & & \\
\hline
\end{tabular}

\subsubsection{Workshop and interviews}


A brief presentation about the research question and objectives, and an overview of the STAMP methodology along with its theoretical underpinnings was presented at the beginning of the workshop and the interviews. The workshop lasted for about an hour, comprising of the introductory session followed by a question and answer segment where the participants provided their feedback about how their organization is involved in road safety. In each of the 16 interview sessions the interviewee was asked a set of questions that aimed to extract information about the existing control and feedback mechanisms working between adjacent and non-adjacent levels. The set of questions asked to each stakeholder are as follows:

1. What are the mandated functions of the organization?

2. Are there any specific functions regarding road safety?

3. How many actors/organizations/departments are under your jurisdiction?

4. What are the processes to control/communicate/interact with the actors of lower levels?

5. Are there any feedback mechanisms from actors of lower levels?

6. Do you provide feedback to the actors of upper levels? If yes, to which controlling agencies/organizations do you provide feedback of your actions and how?

7. How do you communicate/interact with other actors in the same level?

For the interviews, at least two of the current authors were present. The workshop was hosted by three of the current authors. Notes were taken during the interviews and workshop, and all sessions were audio recorded for future references. Any contradictory answers or discussion points raised by the participants were discussed and resolved during the session. After the workshop and interviews, recordings and notes were used to update 
the STAMP control structure. This updated version was then sent, via email, to the 16 interview participants for further validation, until the final STAMP model was accepted.

\section{Results}

The STAMP control structure model representing the Bangladesh road safety system is presented in Figures 2 and 3. Both sides are presented together as one full STAMP control structure model in the Appendix. The model consists of two distinct parts, namely System Development and System Operation (Leveson, 2004). In Figures 2 and 3, control mechanisms imposed by actors and/or organizations at a specific level on adjacent bottom level actors and/or organizations are represented by downward flowing solid straight arrows and regular sized texts. For depicting control mechanisms between non-adjacent levels, downward flowing solid curved arrows and italic text has been used. Feedback mechanisms representing the flow of information provided by actors and/or organizations at a specific level to the adjacent higher-level actors and/or organizations are represented by upward flowing dashed straight arrows and plain text. For representing control mechanisms between non-adjacent levels, upward flowing dashed curved arrows and italic text has been used. 


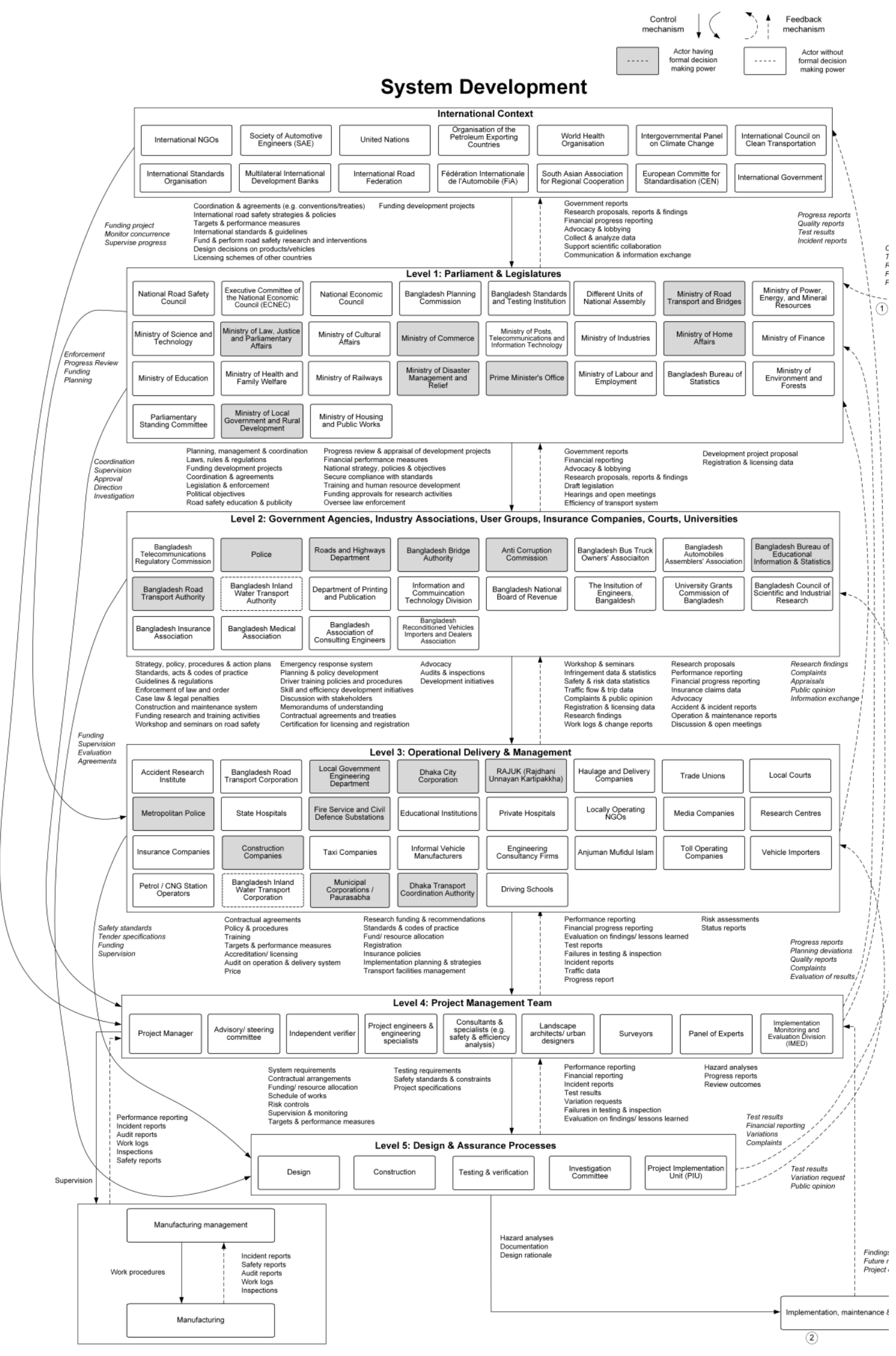

Figure 2: STAMP control structure model (System Development) of the Bangladesh road safety system 


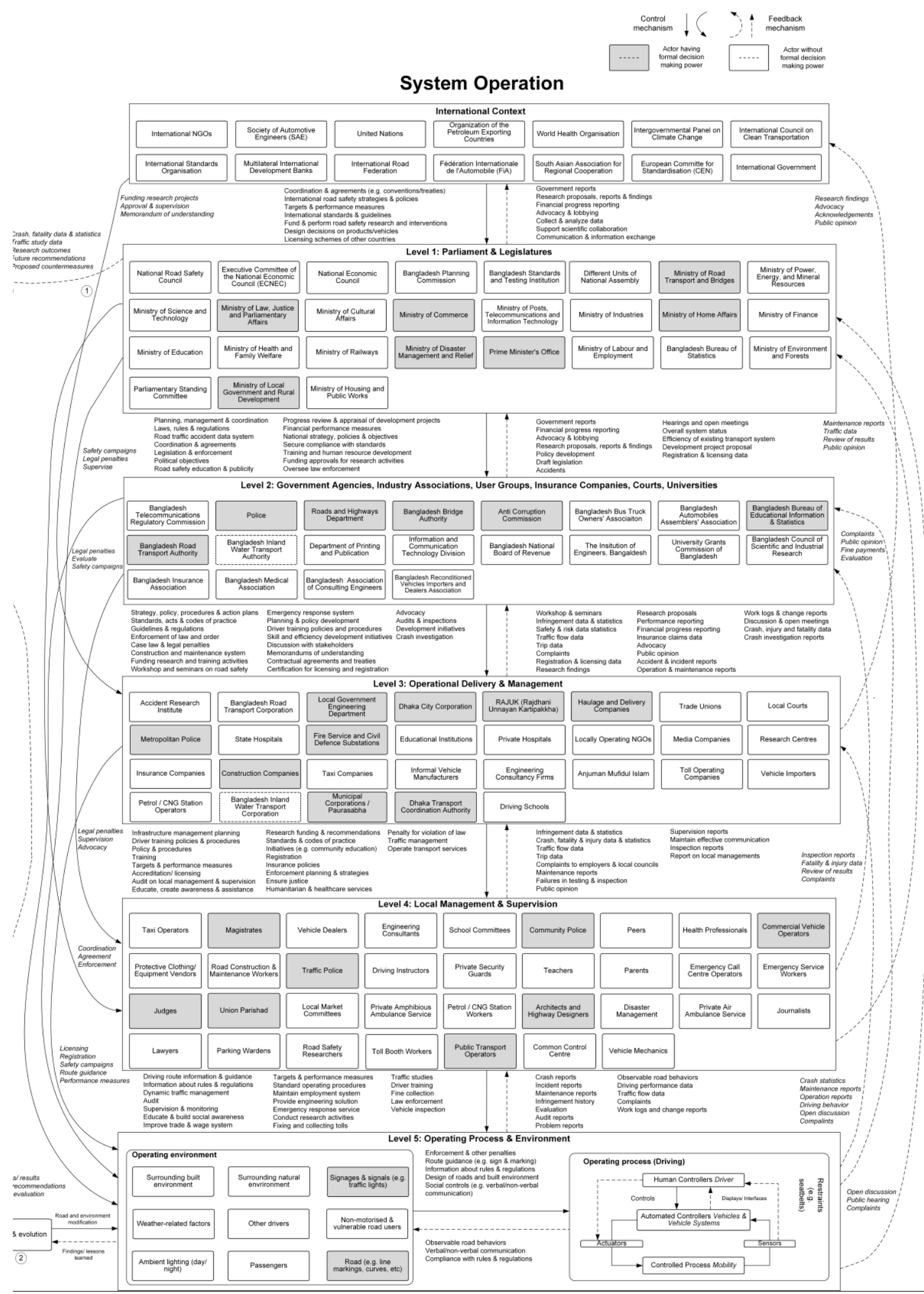

Figure 3: STAMP control structure model (System Operation) of the Bangladesh road safety system 


\subsection{International Context}

At the top of the system resides the international organizations influencing road safety in Bangladesh, independent of the government e.g., international NGOs responsible for road safety campaigns. In the system development part, these actors control actors at the level below through, e.g., agreements, funding, policies, standards and guidelines, promotion of research activities etc. During the operation phase, funding as a control is absent. Feedback from the next level down, Level 1, is provided in the form of research proposals and reports, lobbying, scientific research collaboration, etc., in both system development and operation.

\subsection{Level 1: Parliament and Legislatures}

Level 1 of the control structure comprises national level committees independent of the government who oversee and review policies and directives, as well as the central government bodies that run the country, e.g., government ministries. The Parliamentary Standing Committee and the Prime Minister's Office have also been included in this level due to their high-level authority in controlling the lower level actors of the system and gathering feedback.

For both system development and operation, the controls enacted by the actors of Level 1 on the actors of Level 2 are achieved through, e.g., planning, management and coordination, legislation, funding, and the setting out of political objectives. During system development activities, actors at Level 1 receive feedback from those directly below, through government and financial reports, draft legislation, hearings and open meetings with the public, and vehicle registration and driver licensing data, etc., whereas additional feedback in the form of policy developments, collision data, and overall system status are acquired during system operation phase. 
3.3. Level 2: Government Agencies, Industry Associations, User Groups, Insurance Companies, Courts, Universities

At Level 2 of the control structure, actors have been included from departments and statutory bodies of state government (e.g., Roads and Highways Department), regulatory authorities (e.g., Bangladesh Road Transport Authority), user groups, societies and associations (e.g., Bangladesh Bus Truck Owner's Association,), and research councils and educational institutions (e.g., Government and Private-owned Universities). During system development there are various forms of control mechanisms imposed by Level 2 actors on Level 3 actors, including policy, codes of practice, legal penalties, construction and maintenance systems, road safety campaigns, licensing, and registration, etc. In system operation, additional controls exist through collision investigation activities.

Feedback mechanisms from lower levels that influence the system development activities are carried out through various forms, such as via statistical reports (on incidents, traffic flows, and trip data), workshops and seminars, public opinion reports, research findings, work logs, performance and financial progress reports, and insurance claims data. During system operation, additional feedback mechanisms exist relating to collision investigation reports and to collated collision, injury, and fatality statistics.

\subsection{Level 3: Operational Delivery and Management}

The actors of this level focus on implementing the functions and services of the levels above it, as well as enforcing laws and carrying out the functions of central government. Although more heavily involved in operations, driving schools develop curricula, haulage and delivery companies and taxi companies have training regimes for their drivers, and 
both state and private hospitals have training programs for emergency response and posttrauma management, hence were also included in the system development branch.

In system design activities, Level 3 actors enact control on Level 4 actors through, e.g., contractual agreements, policy and procedures, training, accreditation and licensing, and transport facilities management. In system operations, controls are enacted through planning infrastructure management, education and enforcement planning and strategies, ensuring justice, humanitarian and healthcare services, traffic management, and operating transport services.

For system development, actors at this level receive feedback from those at the level below in the form of performance and financial progress reports, testing, inspection, and incident reports, traffic data. For system operation, feedback is acquired in the form of collision, fatality, and injury data, traffic flow and trip data, complaints to employers and local councils, and maintenance, inspection, and management reports.

\subsection{Level 4: Project Management Team/Local Management and Supervision}

Level 4 of the system development control structure involves all the actors included in project management required to successfully implement a project. In the system operation phase, actors at this level are involved in local management and supervision with an aim to fulfill national objectives in a localized context.

The Project Management Team residing at Level 4 of the system development aspect enacts control over actors in the lower level by imposing system requirements, the allocation of resources, schedules of works, testing requirements, safety standards, project specifications, etc. In return, from Level 5, feedback is drawn through performance and financial reporting, incident reports, test results, variation requests, inspections, etc. The Project Management Team also supervises the manufacturing segment and acquires 
feedback such as performance reporting, incident reports, audit report, work logs, inspections, and safety reports.

For system development, the actors included in the Local Management and Supervision level enact controls on actors in the lower level in various forms, such as through driving route information and guidance, dynamic traffic management, building social awareness, trade and wage provision, emergency response services, traffic studies, driver training, and vehicle inspection. In return, the lower level actors provide feedback through crash and incident reports, evaluation, and audit reports, driving performance data, complaints from the public, etc.

\subsection{Level 5: Design and Assurance Processes/ Operating Process and Environment}

Level 5 of the system development control structure denotes the design, construction, testing and verification processes. In order to accomplish these processes, the Project Implementation Unit (PIU), which ensures compliances to the specifications as per tender documents, and the Investigation committee, under executive direction from the ministry, work in cohort. The actors of this level enact control on the implementation, maintenance, and evolution phase by providing hazard analyses, documentation, and design rationales.

The lowest level of the system operation side of the STAMP control structure involves the operating processes and surrounding environment. This level incorporates the vehicles plying on the roads, the drivers of those vehicles, the surrounding natural and built-up environment, weather and ambient conditions, the road and related infrastructure, and other road users. At this level, drivers exert control over their vehicles (e.g., via the gas pedal) and in return the vehicle provides feedback about its current status and performance (e.g., via the instrument cluster). External to the vehicles, the surrounding environment controls driver behavior through enforcement and penalties (e.g., via CCTV cameras), road 
geometry, traffic signs and markings, and social controls exist in the form of verbal and non-verbal communication with other road users. Individual drivers provide feedback to the operating environment via their observable road behaviors (compliance with existing traffic laws, rules, and regulations) and communication with other road users (e.g., physical gestures).

\subsection{Manufacturing Management}

At the bottom of the system development control structure lies the manufacturing management and manufacturing process. Manufacturing management controls the manufacturing process through work procedures and in return receives feedback in the form of incident reports, safety reports, audit reports, work logs and inspections.

\subsection{Control and Feedback Mechanisms Between Non-Adjacent Levels}

In addition to control and feedback mechanisms existing between adjacent levels, some actors also enact control upon and receive feedback from non-adjacent levels, during both system development and operation. For example, during system development, control and feedback mechanisms exist between actors at the International Context and Parliament and Legislatures Levels and the Project Management Team at Level 4. Top level actors also have significant control over Level 3 actors, and acquire necessary feedback. Level 2 and Level 3 actors both enact control over and receive feedback from Level 5 actors.

In system operation, control and feedback mechanisms exist between international organizations and Level 3 actors. Level 1 actors exert control and acquire feedback from actors corresponding to both the Local Management and Supervision at Level 4 and the Operating Process and Environment at Level 5. Level 2 actors also exert control over the actors at Level 4 and Level 5, and receive feedback in return. Additionally, Level 3 actors 
involved in Operational Delivery and Management enact control on Level 5 actors and feedback in various forms is communicated up the system.

\subsection{Linkage Between System Development and System Operation}

Controlled by Level 5 of the System Development phase, implementation, maintenance, and evolution works as the linking part between the development and operation phases of the system by providing feedback to the Project Management Team via findings, future recommendations, and project evaluations. It also controls the bottom most level of the System Operation control structure through road and environment modification, and gets feedback in the form of findings and lessons learned. At the Parliament and Legislatures level, fatality data statistics, traffic research outcomes, and future recommendations and proposed countermeasures from the System Operation segment are used as feedback to Level 1 of the System Development phase. This information is incorporated into system design for developing an engineered system adapted to the requirements.

\subsection{Differences in Control and Feedback Mechanisms Between System Development and System Operation}

Differences between system development and system operation, in terms of the control and feedback mechanisms present, have been identified and are presented in Table 2. From a control perspective, funding activities are evident in system development but are absent from system operation; collision investigation is absent during system development but present during operation (for obvious reasons); planning related to infrastructure management, enforcement, and driver training are evident in system operation but missing from system development. At the top of the system, from a feedback perspective, collision data, investigation reports, traffic data, and maintenance reports are acquired only during 
system operation (it is not possible to acquire such data during system development due to the absence of collisions and active traffic in this phase); feedback regarding policy developments related to infrastructure management, enforcement, traffic management, and driver training are acquired during system operation but not in system development, nor are they shared, even though policy development is a vital part of this phase. At lower levels of the system, controls related to project specific system requirements, hazard analyses, and work procedures are manifested in system development whereas controls pertaining to local management and supervision, interaction among drivers, vehicles and the environment are evident in system operation; this leads to a lack of synergy between project management, design and implementation, and local management and supervision, operating processes and environment. From a feedback perspective, financial reporting, performance progress, work logs, and findings and recommendations are evident in system development at the bottom of the system. By way of contrast, collision reports, infringement statistics, driving performance data, and complaints from public are evident in feedback from system operation. This highlights a lack of the overlapping of information and data sharing required to connect system development and system operation.

Table 2. Control and feedback differences between system development and system operation

\begin{tabular}{|c|c|c|c|c|}
\hline \multirow{2}{*}{ System Level } & \multicolumn{2}{|c|}{ Control differences } & \multicolumn{2}{|c|}{ Feedback differences } \\
\hline & System Development & System Operation & System Development & System Operation \\
\hline International Context & $\begin{array}{l}\text { Funding development } \\
\text { projects }\end{array}$ & $\begin{array}{l}\text { Funding activities are absent during } \\
\text { system operation }\end{array}$ & --- & --- \\
\hline $\begin{array}{l}\text { Level 1: Parliament } \\
\text { \& Legislatures }\end{array}$ & -- & --- & $\begin{array}{l}\text { Policy updates and } \\
\text { collision data recordings } \\
\text { are redundant in system } \\
\text { development }\end{array}$ & $\begin{array}{l}\text { Feedback is acquired as } \\
\text { policy developments, } \\
\text { collision data and } \\
\text { overall system status }\end{array}$ \\
\hline $\begin{array}{l}\text { Level 2: Government } \\
\text { Agencies, Industry } \\
\text { Associations, User } \\
\text { Groups, Insurance } \\
\text { Companies, Courts, } \\
\text { Universities }\end{array}$ & $\begin{array}{l}\text { Collisions do not } \\
\text { occur during system } \\
\text { development, so } \\
\text { investigations are not } \\
\text { required }\end{array}$ & Collision investigation & $\begin{array}{l}\text { Collision feedback are } \\
\text { needless due to absence } \\
\text { of collision occurrence }\end{array}$ & $\begin{array}{l}\text { Feedback regarding } \\
\text { collision, injury, fatality } \\
\text { rates, and collision } \\
\text { investigation reports are } \\
\text { acquired }\end{array}$ \\
\hline
\end{tabular}




\begin{tabular}{|c|c|c|c|c|}
\hline $\begin{array}{l}\text { Level 3: Operational } \\
\text { Delivery \& } \\
\text { Management }\end{array}$ & $\begin{array}{l}\text { Planning related to } \\
\text { infrastructure } \\
\text { management, } \\
\text { enforcement, traffic } \\
\text { management, driver } \\
\text { trainings are not } \\
\text { mandated during } \\
\text { system development }\end{array}$ & $\begin{array}{l}\text { Planning infrastructure } \\
\text { management, driver training } \\
\text { policies, targets, accreditation or } \\
\text { licensing, audits, education, research } \\
\text { funding and recommendations, } \\
\text { standards and codes of practice, } \\
\text { registration and insurance policies, } \\
\text { enforcement planning and strategies, } \\
\text { ensuring justice, humanitarian and } \\
\text { healthcare services, traffic } \\
\text { management, and operating } \\
\text { transport services }\end{array}$ & $\begin{array}{l}\text { Traffic data, collision } \\
\text { data, complaints, } \\
\text { maintenance, inspection, } \\
\text { and management reports } \\
\text { are non-essential in } \\
\text { system development }\end{array}$ & $\begin{array}{l}\text { Feedback in the form of } \\
\text { infringement data, } \\
\text { collision, fatality, and } \\
\text { injury data, traffic flow } \\
\text { and trip data, } \\
\text { complaints to } \\
\text { employers and local } \\
\text { councils, and } \\
\text { maintenance, } \\
\text { inspection, and } \\
\text { management reports are } \\
\text { acquired }\end{array}$ \\
\hline $\begin{array}{l}\text { Level 4: Project } \\
\text { Management Team/ } \\
\text { Local Management \& } \\
\text { Supervision }\end{array}$ & $\begin{array}{l}\text { Imposes system } \\
\text { requirements, allocates } \\
\text { resources, schedules of } \\
\text { works, set risk } \\
\text { controls, targets and } \\
\text { performance measures, } \\
\text { testing requirements, } \\
\text { safety standards, and } \\
\text { project specifications }\end{array}$ & $\begin{array}{l}\text { Focuses on fulfilling national } \\
\text { objectives in a localized context } \\
\text { through driving route information } \\
\text { and guidance, information about } \\
\text { rules and regulations, dynamic } \\
\text { traffic management, audits, } \\
\text { supervision and monitoring, } \\
\text { building social awareness, trade and } \\
\text { wage provision, targets and } \\
\text { performance measures, standard } \\
\text { operating procedures, emergency } \\
\text { response services, tolls, traffic } \\
\text { studies, driver training, law } \\
\text { enforcement, and vehicle inspection. }\end{array}$ & $\begin{array}{l}\text { Performance and } \\
\text { financial reporting, } \\
\text { incident reports, test } \\
\text { results, variation } \\
\text { requests, inspections, } \\
\text { evaluations of findings } \\
\text { and lessons learned, and } \\
\text { reviews of outcomes are } \\
\text { acquired in the form of } \\
\text { feedback }\end{array}$ & $\begin{array}{l}\text { Crash and incident } \\
\text { reports, maintenance } \\
\text { reports, infringement } \\
\text { histories, evaluation and } \\
\text { audit reports, problem } \\
\text { reports, observable road } \\
\text { behaviors, driving } \\
\text { performance data, } \\
\text { traffic flow data, } \\
\text { complaints from the } \\
\text { public, and work logs } \\
\text { and change reports are } \\
\text { acquired as feedback }\end{array}$ \\
\hline $\begin{array}{l}\text { Level 5: Design \& } \\
\text { Assurance Processes/ } \\
\text { Operating Process \& } \\
\text { Environment }\end{array}$ & $\begin{array}{l}\text { Hazard analyses, } \\
\text { documentation and } \\
\text { design rationale are } \\
\text { enacted }\end{array}$ & $\begin{array}{l}\text { Drivers control vehicles and } \\
\text { surrounding environment controls } \\
\text { driver behavior }\end{array}$ & $\begin{array}{l}\text { Findings, future } \\
\text { recommendations, and } \\
\text { project evaluations are } \\
\text { reported }\end{array}$ & $\begin{array}{l}\text { Drivers interact with } \\
\text { environment and other } \\
\text { road users through } \\
\text { observable road } \\
\text { behaviors }\end{array}$ \\
\hline $\begin{array}{l}\text { Implementation, } \\
\text { maintenance \& } \\
\text { evolution }\end{array}$ & --- & $\begin{array}{l}\text { Modification of road and } \\
\text { environment }\end{array}$ & --- & $\begin{array}{l}\text { Feedback are provided } \\
\text { in the form of findings } \\
\text { and lessons learned }\end{array}$ \\
\hline Manufacturing & $\begin{array}{l}\text { Work procedures } \\
\text { control manufacturing } \\
\text { process }\end{array}$ & $\begin{array}{l}\text { System operation does not involve } \\
\text { control mechanisms in } \\
\text { manufacturing }\end{array}$ & $\begin{array}{l}\text { Receives incident } \\
\text { reports, safety reports, } \\
\text { audit reports, work logs } \\
\text { and inspections }\end{array}$ & $\begin{array}{l}\text { System operation does } \\
\text { not involve feedback } \\
\text { mechanisms in } \\
\text { manufacturing }\end{array}$ \\
\hline
\end{tabular}

\section{Discussion}

The aim of this research was to develop a control structure model of the Bangladesh road safety system in order to delineate the responsibilities of different actors residing at different levels of the system and in the process draw attention to shortfalls in existing control and feedback mechanisms. Motivated by the research of Salmon et al. (2016), which was focused primarily on the operations side of a STAMP control structure model of a high-income country's road safety system, our research focuses on the road safety system of a low-income country (i.e., Bangladesh), and looks at both system development and system operation. In recent times, road safety strategies worldwide are acknowledging the shared responsibilities of actors at different hierarchical levels of the system, and 
emphasizing the importance of considering the overall system and the interrelationships among different entities (Salmon et al., 2012a; Salmon et al., 2016; McIlroy et al., 2019; Hamim et al., 2019, 2020a, 2020b). This was the aim of our research; to shed light on system inter-connectivity and the interactions between different levels of the hierarchical road safety system that affect its performance, thereby drawing attention to the systemwide factors that influence road safety in Bangladesh.

Actors represented in the STAMP model in Figures 2 and 3 are same for the top four system levels for development and operation. This characteristic is not usually found while applying such models in manufacturing companies involving separate actors designated for carrying out development and operation (Leveson, 2004). In the road safety domain, however, actors involved in developing the system will typically also operate the system. Although in many cases those actors use separate chains of command for development and operation, this would need a more detailed system representation than a whole-system STAMP model can legibly provide (e.g., the Roads and Highways Department (RHD) has a 'Design and Planning Division' which is involved in designing geometric and structural elements of roads, and a 'Working Division' which is devoted to construction and maintenance activities). The STAMP model presented above reveals that systematic control and feedback loops exist across the overall Bangladesh road safety system, but these control and feedback loops may also be present within the levels. Due to the high complexity of the Bangladesh road system, and the large number of actors involved, it would be difficult to legibly (and therefore usefully) represent within level interactions in the single STAMP control structure model.

Differences in control and feedback mechanisms between the development and operation phases of the system reflect that funding activities are existent only in the development phase, while activities pertaining to enforcing laws, managing infrastructure, 
and training drivers are included only in system operation. During system development, there will be no road collisions, but once a system starts its operation these will occur. This leads to the need for crash investigation activities and the associated feedback mechanisms (i.e., crash data and investigation reports). Also, it is clear from the observed differences at Level 1 that feedback on policy development obtained during system operation phase is not being implemented in the development of the system. It is essential that feedback related to policy improvement received during system operation is shared and utilized during system development. Control and feedback mechanisms related to project management, design and implementation are also carried out during system development, whereas local management, supervision, operating processes, and environment related controls and feedback are enacted during the system operation phase. In Bangladesh, this occurs without any co-ordination among these levels; this leads to difficulties in operation after projects are implemented. At the bottom of the system, progress reports, findings, and recommendations for improvement are fed back to system development, whereas collision reports, traffic data, and public complaints are acquired during system operation. There is a deficiency in the information and data sharing necessary to create synergy between system development and operation phases.

Salmon et al. (2016) argued that STAMP analyses undertaken in different income settings would likely yield different results; our results support this. To our knowledge the analyses presented above represent the first attempt to model a complex sociotechnical system using the STAMP methodology in a low-income setting. Although an international comparison was not the main focus of our work, it is worth noting that a major difference between high-income and low-income countries is, of course, the availability of funds. Low-income countries tend to have a strong focus on development initiatives, with road safety less appealing in terms of showcasing the achievements of government (compared 
to the construction of new infrastructure). On the other hand, in high-income countries the focus can be more on improving an already well-developed system, hence road safety represents more of a priority in comparison with low-income countries. In the Bangladesh road safety system, this manifests as a constraint that forces actors at the policy level to prepare priority lists; these may halt the usual control and feedback mechanisms. It has been argued by Leveson (2012) that insufficient resources (e.g., personnel, time, equipment, money) force people involved in safety plans (either at the design or the implementation stage) to make allocation decisions, decisions that ultimately result in safety being compromised. The implementation of projects, particularly in low income countries like Bangladesh, face serious political interference given these ministry-led priority levels. In some instances, this can be a significant hindrance to safety; as the political landscape changes, so do priorities, hence long-term projects can be rushed, stopped, or abandoned before they have commenced. However, this can also be interpreted in a positive sense, insofar as direct influence from upper level actors makes project implementation easier for those actors involved in implementation and operational delivery, as inter-level control and feedback mechanisms (which can sometimes represent barriers to progress, often through excessive bureaucracy) are bypassed. This indicates that differences in the various levels of the control structure exist between low-income and high-income countries. Again, although such a detailed comparison was not the objective of our study, this highlights a useful avenue for future research. Indeed, the presence of non-adjacent level interactions represents a notable difference between the STAMP model presented here, and that of the Queensland (Australia) road transport system presented by Salmon et al. (2016); in that high-income setting there were fewer control and feedback loops between non-adjacent levels than in our low-income setting. This is, at least in part, due to a reluctance to follow systematic procedures coupled with political bias towards 
performing certain activities, or pursuing certain projects (e.g., where an elected official has an idea about which they are passionate); this is quite common in development driven, low-income countries, a point that was mentioned by a number of our interviewees.

Although in many cases the feedback mechanisms and controls identified in our research are the same as those identified for the Queensland road transport STAMP model, those mechanisms do not necessarily function to the same level in both settings. For example, incident data, infringement statistics and fatality rates are fed from bottom levels towards upper levels, in both settings. This mechanism is not, however, functioning properly in Bangladesh. In the World Health Organization's most recent Global Status Report on Road Safety (WHO, 2018), the estimated annual road traffic fatalities in Bangladesh was 24,954; traffic fatalities reported by the Bangladesh Police was 2,376, less than one-tenth of the value estimated by the WHO. There are many factors contributing to this, with the use of only police data (counting only those that die at the scene of the collision) being a significant factor. The joined-up, multi-sector systems of data collection and dissemination that are necessary, and that are seen in higher-income settings, simply do not yet exist in Bangladesh, or in many other low- and middle-income settings (e.g., Heydari et al. 2019). This is compounded by the active suppression of fatality numbers; it was revealed in our stakeholder interviews that a practice has been established in Bangladesh whereby individuals with decision-making authority are rewarded when the number of incidents and fatalities reduces. Such a strategy encourages the withholding of information, thus creating the illusion that the system is becoming safer. In reality, the opposite is true; the problem has merely been 'muted' (Turner and Pidgeon, 1997). Moreover, with a general lack of structures supporting the feeding back of information from lower to higher levels, personnel may be reluctant to report, since the information provided by them will disappear into a black hole, without any likelihood of response 
(Leveson, 2012). Another perception is that if such information were provided to the upper levels, the actors responsible for developing policies and strategies would be overwhelmed, and would not be able to come up with interventions that tackle such a large challenge. That said, without reliable, functioning feedback mechanisms, it will be impossible to make roads safer for the users.

One of the key features of the control structure model developed for the Bangladesh road safety system is its ability to represent the control and feedback loops between nonadjacent levels. Discussion with stakeholders from the Project Management Team level revealed a striking fact about the current norms of project design and implementation in Bangladesh. Firstly, many international donor agencies directly fund development projects and oversee progress, ignoring the intermediary levels of the system. Also, actors from the Parliament and Legislatures level, such as the Prime Minister's office, directly influence the design and implementation of projects, thereby superseding lower level actors. These overpowering mechanisms eventually bring instability to the overall system and decrease efficiency. Another potential source of failure, or sub-optimal performance, in the system, relates to the disconnect between funder, developer, and operator. Projects are often funded by national or international donors, and then designed and implemented by a certain entity from the Government Agencies level. After project completion, however, responsibility for operation and maintenance is commonly handed over to an entity from the Operational Delivery and Management Level, even though this organization was never involved during design and implementation phase. For example, the Uttara and Purbachal residential area in Dhaka was developed by Rajdhani Unnayan Kartipakkha (RAJUK; a public agency responsible for coordinating urban development in Dhaka); however, it is the Dhaka City Corporation that now has responsibility for maintenance of the areas, and for day-to-day operations. Stakeholder interviewees of our study involved in project management pointed 
out that the influence of external, international funders is much larger in Bangladesh, in the case of the design and implementation of projects, than would be expected in high-income settings, where internal resources are higher. This adds complexity to the process. For example, a traffic signalization project in Dhaka city was funded by the World Bank, and implemented by the Dhaka City Corporation; however, it will be operated by the Bangladesh Police. The police were never consulted during design and implementation phase, despite being the intended end user. This, and the previous example, highlight the inconsistencies and lack of integration in the development driven system, and the poor connections to the operation of the system. This is common across many low- and middleincome countries, and is something that negatively affects the safety and sustainability of the overall road safety system by breaking the standard control and feedback mechanisms.

\section{Limitations and Future Work}

In developing the STAMP control structure model, the main source of information acquisition and validation lies in stakeholder engagement. In this study, workshops and interviews were adopted. As with any other method, interviews have their own disadvantages. For example, with face-to-face interviews and workshops there is a lack of anonymity, which could lead to bias in the answers given (for example, through a subconscious desire to give positive responses). To combat this, participants were asked supplementary questions if only positive responses were received; however, limitation remains. Additionally, resource constraints also dictate a relatively small number of participants in comparison with, for example, the Delphi study method. In Salmon et al.'s (2016) work, the Delphi study approach, with multiple rounds, was used to engage multiple stakeholders (see also Holmes et al., 2019); however, due to the requirement of multiple feedback rounds, there is a potential for high drop-out rates (Hsu and Sandford, 2007). 
Hence, interviews and workshops were conducted in order to gather more detailed information with the possibility for spontaneous question and discussion.

In order to validate the STAMP model, input from at least one stakeholder from every level of the system was sought. But it must be noted that every level has various organizations, so interviewing one person from an organization might not be representative of the whole level, and even multiple stakeholders from same organization would likely provide different perspectives of that organization's activities. Publicly available documents, the academic literature, and authors' experience and knowledge of the road safety domain went some way to address this challenge; however, the limitation must be recognized.

The STAMP model presented in this study represents a model of the overall road safety system in Bangladesh, not a collision or event. One could justifiably argue that the analysis above is not complete, insofar as it does not include all the actors could be involved in some way. That said, for reasons of parsimony and succinctness, it would be neither possible nor useful to try and include all possible components of the entire road safety system. Rather, the aim was to include the most impactful and relevant components. This was then reviewed and validated by the subject matter experts. Although a different analysis, developed with the input of different subject matter experts, might show some differences with the analysis we present above; however, this would not equate to the nonvalidity of our analysis. The road transport system is inherently complex, and there are many ways for it to be viewed and understood.

The STAMP control structure is a useful tool for developing an understanding of road transport systems (Salmon et al., 2016), but such in-depth analyses require data collection procedures designed to collect factors beyond the road users, road environment and vehicles (Salmon and Lenné, 2015). The Accident Report Form (ARF) currently used 
in Bangladesh for the recording of collision data does not satisfy this requirement as it only requires detailing of information related to the end users involved in the collisions, and the immediate physical environment in which it occurred. There is therefore scope for further research to examine the possibilities of crash report forms informed by systems thinking. Such development could occur alongside performance of System-Theoretic Process Analysis (STPA), a predictive approach based on STAMP models and theory that assesses potential risk factors and provides intervention design guidance before incidents actually occur.

\section{Conclusions}

This paper presented a STAMP based control structure model for the Bangladesh road safety system, incorporating control and feedback loops instantiated in both the development and operation phases of the system. This represents the first attempt to apply the STAMP methodology in a low-income setting. Interaction amongst the actors between adjacent and non-adjacent levels have been represented in the model. It has been argued that understanding the mechanisms influencing control and feedback processes has greater benefits in formulating required interventions to make an overall safer road system than looking at the components (or actors) in isolation. The existing inconsistencies in the road safety system of Bangladesh have been delineated, many of which are common to other low- and middle-income countries. Political interference and behavior of upper level actors over lower level actors could deteriorate the overall system in design as well as operation. In addition, a disconnect between large funders involved in development and the actors and organizations responsible for maintenance and operation hinder system sustainability as well as safety. Overall, a lack of synergy between actors of different levels was found to be hampering the efficiency of the system. Although such models can help us to 
understand and explain complex sociotechnical systems (such as road safety), it requires comprehensive data population to validate the control structure. Given the narrow focus of current incident reporting techniques, there is scope for future research to incorporate factors from higher levels when collecting incident data, and for predictive models that can guide the design of interventions that tackle current as well as future problems.

\section{Acknowledgments}

This research was funded by the National Institute for Health Research (NIHR; 16/137/122) using UK aid from the UK Government to support global health research. The views expressed in this publication are those of the author(s) and not necessarily those of the NIHR or the UK Department of Health and Social Care.

\section{References}

Carayon, P., Hancock, P., Leveson, N., Noy, I., Sznelwar, L., van Hootegem, G., 2015. Advancing a sociotechnical systems approach to workplace safety - developing the conceptual framework, Ergonomics, 58(4), 548-564, DOI: 10.1080/00140139.2015. 1015623.

Cornelissen, M., Salmon, P.M., McClure, R., Stanton, N.A., 2013. Using cognitive work analysis and the strategies analysis diagram to understand variability in road user behaviour at intersections. Ergonomics, 56 (5), 764-780.

Cornelissen, M., Salmon, P.M., McClure, R., Stanton, N.A., 2015. Assessing the 'system' in safe systems-based road designs: using cognitive work analysis to evaluate intersection designs. Accid. Anal. Prev. 74, 324-338.

Davis, M.C., Hughes, H.P.N., McKay, A., Robinson, M.A., van der Wal, C. N., 2020. Ergonomists as designers: computational modelling and simulation of complex sociotechnical systems, Ergonomics, 63(8), 938-951, DOI: 10.1080/00140139.2019. 1682186.

Dekker, S., 2011. Drift into Failure: from Hunting Broken Components to Understanding Complex Systems. Ashgate, Aldershot, UK. 
Elvik, R., 2010. Why some road safety problems are more difficult to solve than others. Accident Analysis and Prevention 42, 1089-1096.

Goh, Y.M., Love, P.E.D., 2012. Methodological application of system dynamics for evaluating traffic safety policy. Saf. Sci. 50 (7), 1594-1605.

Hamim, O.F., Hoque, M.S., McIlroy, R.C., Plant, K.L., Stanton, N.A., 2019. Applying the AcciMap methodology to investigate the tragic Mirsharai road accident in Bangladesh. Proc. MATEC Web Conf. 277, 02019.

Hamim, O.F., Hoque, M.S., McIlroy, R.C., Plant, K.L., Stanton, N.A., 2020a. A sociotechnical approach to accident analysis in a low-income setting: Using Accimaps to guide road safety recommendations in Bangladesh. Safety Science, 124. DOI: 10.1016/j.ssci.2019.104589

Hamim, O.F., Hoque, M.S., McIlroy, R.C., Plant, K.L., Stanton, N.A., 2020b. Representing two road traffic collisions in one Accimap: highlighting the importance of emergency response and enforcement in a low-income country, Ergonomics, 63 (12), 1512-1524. DOI: $10.1080 / 00140139.2020 .1807064$

Heydari, S., Hickford, A., McIlroy, R., Turner, J., \& Bachani, A. M., 2019. Road safety in low-income countries: state of knowledge and future directions. Sustainability, 11(22), 6249

Holman, M., Walker, G., Lansdown, T., Hulme, A., 2020. Radical systems thinking and the future role of computational modelling in ergonomics: an exploration of agent-based modelling, Ergonomics, 63(8), 1057-1074, DOI: 10.1080/00140139.2019.1694173.

Holmes, G., Clacy, A., Salmon, P.M., 2019. Sports-related concussion management as a control problem: using STAMP to examine concussion management in community rugby, Ergonomics, 62 (11), 1485-1494.

Hsu, C.-C., \& Sandford, B. A., 2007. The Delphi technique: making sense of consensus. Practical assessment, research \& evaluation, 12(10), 1-8.

Jamot, D.G.C., Park, J.Y., 2019. System theory based hazard analysis for construction site safety: A case study from Cameroon. Safety Science, 118, 783-794.

Kazaras, K., Kontogiannis, T., Kirytopoulos, K., 2014. Proactive Assessment of Breaches of Safety Constraints and Causal Organizational Breakdowns in Complex Systems: A Joint STAMP-VSM Framework for Safety Assessment. Safety Science, 62, 233-247.

Larsson, P., Dekker, S.W.A., Tingvall, C., 2010. The need for a systems theory approach to road safety. Saf. Sci. 48 (9), 1167-1174. 
Leveson, N., 2004. A new accident model for engineering safer systems. Safety Sci. 42, $237-270$.

Leveson, N.G., 2012. Engineering a Safer World: Systems Thinking Applied to Safety. MIT Press, Cambridge.

Lintern, G., Kugler, P.N., 2017. Sociotechnical System Safety: Hierarchical Control versus Mindfulness. Systems Engineering, 20(4), 307-317.

McClure, R.J., Adriazola-Steil, C., Mulvihill, C., Fitzharris, M., Bonnington, P., Salmon, P.M., Stevenson, M., 2015. Simulating the dynamic effect of land use and transport policies on the development and health of populations. Am. J. Public Health 105 (S2), 223-229.

McIlroy, R.C., Plant, K.A., Hoque, M.S., Wu, J., Kokwaro, G.O., Nam, V.H., \& Stanton, N.A., 2019. Who is responsible for global road safety? A cross-cultural comparison of Actor Maps. Accident Analysis and Prevention, 122, 8-18.

Newnam, S., Goode, N., 2015. Do not blame the driver: a systems analysis of the causes of road freight crashes. Accid. Anal. Prev. 76, 141-151.

Parand, A., Faiella, G., Franklin, B.D., Johnston, M., Clemente, F., Stanton, N.A., Sevdalis, N., 2018. A Prospective Risk Assessment of Informal Carers' Medication Administration Errors within the Domiciliary Setting, Ergonomics, 61(1), 104-121, DOI: 10.1080/ 00140139.2017.1330491.

Rasmussen, J., 1997. Risk management in a dynamic society: a modelling problem. Safety Science, 110, (2/3), 183-213.

Read, G., Salmon, P.M., Lenné, M.G., 2013. Sounding the warning bells: the need for a systems approach to rail level crossing safety. Appl. Ergon. 44, 764-774.

Salmon, P. M., Read, G. J., \& Stevens, N. J., 2016. Who is in control of road safety? A STAMP control structure analysis of the road transport system in Queensland, Australia. Accident Analysis \& Prevention, 96, 140-151.

Salmon, P.M., G.M. Read, N.A. Stanton, and M.G. Lenné. 2013. The Crash at Kerang: Investigating Systemic and Psychological Factors Leading to Unintentional Noncompliance at Rail Level Crossings. Accident Analysis and Prevention, 50, 1278-1288.

Salmon, P.M., Lenné, M.G., 2015. Miles away or just around the corner: systems thinking in road safety research and practice. Accid. Anal. Prev. 74, 243-249.

Salmon, P.M., McClure, R., Stanton, N.A., 2012a. Road transport in drift? Applying contemporary systems thinking to road safety. Saf. Sci. 50 (9), 1829-1838. 
Salmon, P.M., Read, G.J.M., 2019. Many model thinking in systems ergonomics: a case study in road safety, Ergonomics, 62(5), 612-628, DOI: 10.1080/00140139.2018. 1550214.

Scott-Parker, B., Goode, N., Salmon, P.M., 2015. The driver, the road, the rest? A systems approach to young driver safety. Accident Analysis and Prevention, 74, 297-305.

Stanton, N. A., Salmon, P. M., Walker, G. H and Stanton, M. 2019a. Models and Methods for Collision Analysis: A Comparison Study based on the Uber collision with a pedestrian. Safety Science, 120, 117-128.

Thatcher, A., Nayak, R., Waterson, P., 2020. Human factors and ergonomics systemsbased tools for understanding and addressing global problems of the twenty-first century, Ergonomics, 63(3), 367-387, DOI: 10.1080/00140139.2019.1646925.

WHO, 2018. Global Status Report on Road Safety 2018. World Health Organisation, Geneva. 
System Development

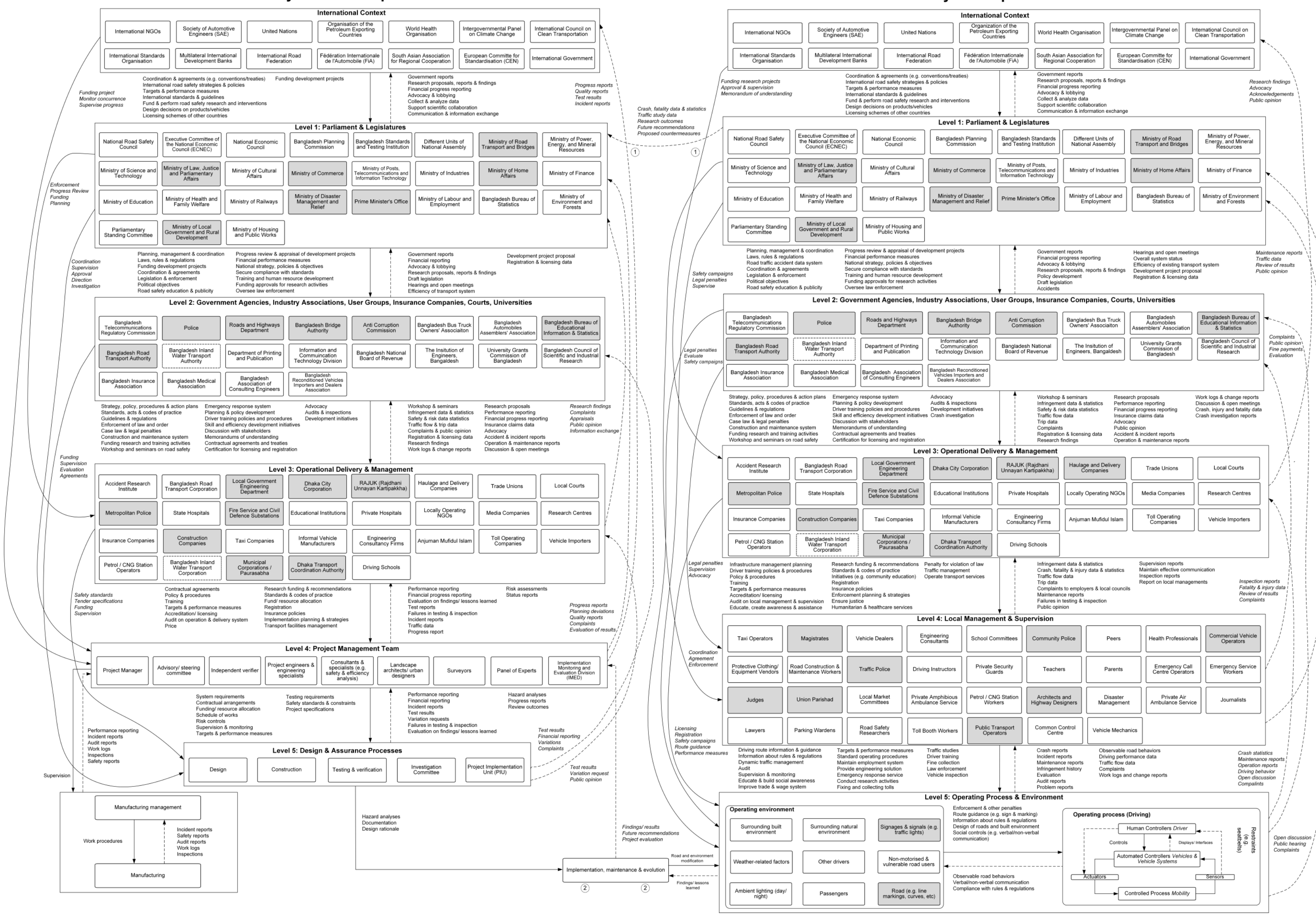

\section{System Operation}

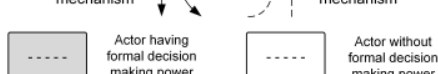

